\title{
HUBUNGAN TEKNIK MENYUSUI DENGAN KEBERHASILAN MENYUSUI PADA BAYI DI RUANG RAWAT INAP AULIA HOSPITAL
}

\author{
Gusman Virgo \\ Program Studi Ilmu Kesehatan Masyarakat Universitas Pahlawan Tuanku Tambusai \\ gusmanvirgo@gmail.com
}

\begin{abstract}
Abstrak
Beberapa faktor yang dapat mempengaruhi keberhasilan menyusui diantaranya adalah Teknik Menyusui. Seperti: posisi menyusui, langkah-langkah dalam menyusui dan keberhasilan dalam menyusui. Kesalahan dalam teknik menyusui dapat mengakibatkan putting susu ibu akan lecet dan menyebabkan bayi tidak dapat menyusu dengan baik yang mengakibatkan bayi menjadi rewel dan gelisah, hal ini disebabkan kerna ketidak berhasilan ibu dalam menyusui bayinta.Tujuan penelitian ini adalah untuk mengetahui hubungan Teknik Menyusui dengan keberhasilan menyusui pada bayi di Ruang Rawat Inap Aulia Hospital Pekanbaru. Desain Penelitian adalah Deskriptif Analitik dengan rancangan Cross Sectional. Populasi dan Sampel dalam penelitian semua ibu post partum yang ada di Ruang Rawat Inap Aulia Hospital Pekanbaru. Pengambilan sampel dilakukan dengan Purposive Sampling yaitu sebanyak 70 responden. Alat pengumpulan data lembar observasi. Data ini dianalisa dengan Analisa Univariat dan Analisa Bivariat. Hasil penelitian berdasarkan uji Chi Square diperoleh hasil ada hubungan antara teknik menyusui dengan keberhasilan menyusui $\mathrm{p}$ value = $0,000<0,05$. Hasil penelitian ini diharapkan dapat menjadi bahan masukan bagi pihak Aulia Hospital agar dapat memberikan penyuluhan tentang manfaat menyusui dan penatalaksanaannya sehingga dapat meminimalisir ketidak berhasilan menyusui
\end{abstract}

Kata Kunci : Asi. Keberhasilan, Teknik Menyusui

Daftar Bacaan : 23 (2009-2019)

@ Jurnal Ners Prodi Sarjana Keperawatan \& Profesi Ners FIK UP 2021

$\triangle$ Corresponding author :

Address : Batu belah, Kampar, Riau

Email : gusmanvirgo@gmail.com

Phone : 085278005288 


\section{PENDAHULUAN}

Air susu ibu (ASI) adalah sumber nutrisi yang primer bagi anak sejak dilahirkan sampai ia mampu mencerna asupan lain setelah usia enam bulan. ASI ini mengandung lemak, protein, karbohidrat, vitamin, mineral, enzim, dan hormon tidak dapat digantikan oleh susu buatan industri (WHO, 2014). Word Health Organization (WHO) menjelaskan bahwa selama pemberian ASI eksklusif ada beberapa cairan yang boleh dikonsumsi oleh bayi yaitu vitamin, suplemen mineral atau obat-obatan, namun hal ini dibolehkan pada bayi yang dalam kondisi tertentu.

Pada tahun 2010 persentase pemberian ASI eksklusif pada bayi usia 0-6 bulan di Indonesia sebesar $15,3 \%$ dan mengalami peningkatan $54,3 \%$ di tahun 2013 dan pada tahun 2015 persentase pemberian ASI eksklusif terjadi peningkatan sebesar 55,3\% (Kementerian Kesehatan RI, 2015). Dari hasil laporan dinas kesehatan provinsi tahun 2013 persentase tertinggi untuk ASI eksklusif terdapat pada Nusa Tenggara Barat sebesar $(79,7 \%)$ sedangkan untuk provinsi terendah terdapat pada propinsi Maluku (35,2\%). Sedangkan untuk Riau sendiri berada di urutan ke 19 dari yang tertinggi sebesar 55,9\% (Infodatin, 2014). Data ini menunjukan bahwa Riau masih ada $44,1 \%$ bayi yang belum mendapatkan ASI eksklusif, Angka ini jauh dari target yang ditentukan oleh pemerintah yaitu sebesar (75\%) (DINKES Provinsi, 2013).

Masalah yang banyak di hadapi oleh ibu menyusui adalah puting susu yang nyeri dan lecet dan paling sering di alami oleh ibu primipara. Masalah puting susu lecet ini $95 \%$ terjadi pada wanita yang menyusui bayinya dengan posisi yang tidak benar yang mana bayi menyusu hanya sampai puting saja tidak sampai pada areola mamae. Berdasarkan penelitian yang dilakukan oleh Rinata (2015) tentang "Teknik Menyusui Yang Benar Ditinjau dari Usia Ibu, Paritas, Usia Gestasi Dan Berat Badan Lahir Di RSUD Sidoarjo" terdapat 53,3\% ibu yang masih salah dalam hal teknik menyusui.

Rumusan masalah penelitian ini adalah apakah ada Hubungan Teknik Menyusui Dengan Keberhasilan Menyusui Pada Bayi Di Ruangan Rawat Inap Aulia Hospital Pekanbaru Sedangkan tujuan umum penelitian ini yaitu Untuk mengetahui Hubungan Teknik Menyusui Dengan Rawat Inap Aulia Hospital Pekanbaru dan tujuan khusus nya yaitu Mengetahui distribusi tentang teknik menyusui di ruangan rawat inap Aulia Hospital Pekan Baru".

Mengetahui distribusi keberhasilan menyusui pada bayi di ruangan rawat inap Aulia Hospital Pekan Baru.mengetahui hubungan tentang teknik menyusui dengan keberhasilan Menyusui Pada Keberhasilan Menyusui Pada Bayi Di Ruangan

Bayi Di Ruangan Rawat Inap Aulia Hospital Pekan Baru".

\section{METODE}

Pada penelitian ini menggunakan rancangan penelitian kuantitatif dengan desain sectional study. Populasi dari penelitian ini adalah $401 \mathrm{ibu}$ post partum di rawat inap Aulia Hospital dari bulan Januari sampai dengan Desember tahun 2020.. Jumlah sampel dalam penelitian ini yaitu 70 orang. Teknik pengambilan sampel dalam penelitian ini menggunakan teknik total purposive sampling.

\section{HASIL DAN PEMBAHASAN}

Penelitian ini bertujuan untuk mengetahui hubungan minat dan dukungan sosial teman sebaya dengan motivasi mahasiswa calon sarjan keperawatan untuk melanjutkan profesi ners. Waktu penelitian yaitu selama satu minggu. Dengan jumlah subjek penelitian sebanyak 62 orang. Dalam pelaksanaannya dibagikan kuesioner kepada subjek untuk mengetahui hubungan antara variabel dengan hasil sebagai berikut.

\section{A. Analisa Univariat}

Analisa univariat mendeskripsikan tentang distribusi karakteristik responden (data umum) yaitu usia, jenis kelamin, minat, dukungan sosial teman sebaya dan motivasi. Adapun analisa univariat dapat dilihat pada tabel berikut:

\begin{tabular}{|c|c|c|c|}
\hline & \multicolumn{3}{|c|}{ 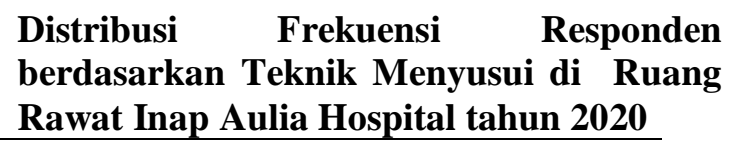 } \\
\hline No & $\begin{array}{c}\text { Teknik } \\
\text { Menyusui }\end{array}$ & $\begin{array}{l}\text { Frekuensi } \\
\text { (n) }\end{array}$ & $\begin{array}{c}\text { Persentase } \\
(\%)\end{array}$ \\
\hline 1 & Tepat & 32 & 45,7 \\
\hline 2 & Tidak tepat & 38 & 54,3 \\
\hline & Total & 70 & 100 \\
\hline \multicolumn{4}{|c|}{$\begin{array}{l}\text { Sumber: Lembar Observasi } \\
\text { dapat dilihat bahwa sebagian besar responden } \\
\text { tidak tepat dalam teknik menyusui yaitu } \\
\text { sebanyak } 38 \text { responden }(54,3 \%) \text { Usia }\end{array}$} \\
\hline & $\begin{array}{l}\text { Distribusi } \\
\text { berdasarkan }\end{array}$ & & $\begin{array}{r}\text { Responden } \\
\text { Keberhasilan }\end{array}$ \\
\hline & $\begin{array}{l}\text { Menyusui di } \\
\text { Hospital tahu }\end{array}$ & $\begin{array}{l}\text { Ruang Ra } \\
2020\end{array}$ & at Inap Aulia \\
\hline
\end{tabular}




\begin{tabular}{|c|c|c|c|}
\hline No & $\begin{array}{c}\text { Keberhasilan } \\
\text { Menyusui }\end{array}$ & $\begin{array}{l}\text { Frekuensi } \\
\text { (n) }\end{array}$ & $\begin{array}{c}\text { Persentase } \\
(\%)\end{array}$ \\
\hline 1 & Berhasil & 30 & 42,9 \\
\hline 2 & $\begin{array}{l}\text { Tidak } \\
\text { Berhasil }\end{array}$ & 40 & 57,1 \\
\hline & Total & 70 & 100 \\
\hline
\end{tabular}

\section{Sumber : Lembar Observasi}

diketahui sebagian besar responden tidak berhasil dalam keberhasilan menyusui yaitu sebanyak 40 responden $(57,1 \%)$.

\section{B. Analisa Bivariat}

Analisa bivariat digunakan untuk mengetahui hubungan teknik menyusui dengan kenerhasilan menyusui . Adapun analisa bivariat dapat dilihat pada tabel berikut ini

\section{Tabel 4.4 Hubungan Teknik Menyusui dengan Keberhasilan Menyusui di Ruang Rawat Inap Aulia Hospital Tahun 2020}

\begin{tabular}{lccccc}
\hline \multirow{2}{*}{$\begin{array}{c}\text { Teknik } \\
\text { Menyusui }\end{array}$} & \multicolumn{3}{c}{ Keberhasilan Menyusui } & To \\
\cline { 2 - 6 } & $\mathbf{2}$ Berhasil & \multicolumn{3}{c}{ Tidak Berhasil } \\
\cline { 2 - 6 } & $\mathbf{N}$ & $\mathbf{\%}$ & $\mathbf{N}$ & $\mathbf{\%}$ & $\mathbf{N}$ \\
\hline Tepat & 28 & 87,5 & 4 & 12,5 & 32 \\
Tidak Tepat & 2 & 5,3 & 36 & 94,7 & 38
\end{tabular}

\begin{tabular}{llllll}
\hline Total & 30 & 42,9 & 40 & 57,1 & 70
\end{tabular}

Keterangan : Hasil penelitian diuji dengan uji statistic Chi Square)

dapat dilihat bahwa dari 32 responden $(100 \%)$ yang tepat dalam teknik menyusui ada 4 responden $(12,5 \%)$ yang tidak berhasil menyusui sedangkan 38 responden $(100 \%)$ yang tidak tepat dalam teknik menyusui ada 2 responden $(5,3 \%)$ yang berhasil dalam menyusui. Berdasarkan uji statistik diperoleh hasil dengan $p$ value $=0,000<$ 0,05 dengan nilai POR 126.0 Ini menjelaskan bahwa ada hubungan yang signifikan antara Teknik Menyusui dengan Keberhasilan Menyusui pada Bayi di Ruangan Rawat Inap Aulia Hospital tahun 2019.

Berdasarkan hasil penelitian diketahui bahwa sebagian besar Teknik Menyusui berada pada rentang tidak tepat sebanyak 38 responden $(54,3 \%)$ Menurut asumsi peneliti hal ini dikarenakan adanya beberapa faktor yang mempengaruhi teknik menyusui diantaranya pengetahuan ibu yang kurang mengenai teknik menyusui dan pengalaman ibu yang kurang , kebiasaan sebelumnya dan saat dilakukan observasi sebgaian besar pendidikan ibu adalah SMA sebanyak 51 responden $(72,9 \%)$

.Berdasarkan hasil penelitian mengenai Keberhasilan Menyusui di Ruang Rawat Inap Aulia Hospital didapatkan hasil bahwa tidak berhasil sebanyak 40 responden $(57,1 \%)$.

Menurut asumsi peneliti hal ini disebabkan karena terdapat masalah dalam proses menyusui seperti perlekatan puting yang tidak baik, posisi yang salah, adanya pembengkakan pada payudara ibu dan saat pengamatan dilapangan banyak ibu menyusui yang mengeluh nyeri pada bekas luka SC dan episotomi pada persalinan spontan serta puting lecet.

Dari hasil penelitian pada responden di Ruang Rawat Inap Aulia Hospital, ditemukan bahwa sebagian besar responden pada kategori teknik menyusui tidak tepat tetapi mengalami keberhasilan menyusui yaitu sebanyak 2 Responden (5,3\%) hal ini dikarenakan adanya dukungan suami serta pengetahuan yang mengenai produksi ASI dan berdasarkan hasil wawancara responden sudah terbiasa dengan teknik menyusui yang diguakan karena responden mengatakan bahwa anak sebelumnya juga seperti ini cara

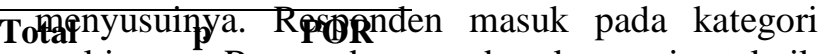
multiparaaluResponden pada kategori teknik menyusui tepat mengalami ketidak berhasilan menyusui yaitu sebanyak 4 Responden $(12,5 \%)$ hal ini\% dikarenakan pengetahuan yang kurang dan kurang petedfya ib26 dengan waktu pemberian ASI pada bayi dan juga disebabkan oleh bentuk putting ibu yang tidak sempurna atau terbelah sehingga bapbikurang puas dalam menyusui dan bayi masih tampak rewel dan gelisah dan berdasarkan hasil wawancara dengan responden, responden mengatakan bahwa masih merasakan nyeri setelah SC sehingga menimbulkan ketidak nyamanan pada ibu saat menyususi. Setelah dilakukan uji statistik untuk melihat hubungan teknik menyusui dengan keberhasilan menyusui di Ruang Rawat Inap Aulia Hospital diperoleh hasil $p$ value $=0,000<0,05$ hal ini menunjukkan bahwa ada hubungan yang signifikan antara melihat hubungan teknik menyusui dengan keberhasilan menyusui di Ruang Rawat Inap Aulia Hospital.

Menurut asumsi peneliti pada responden yang memiliki teknik menyusui tepat tapi tidak berhasil menyusui bisa disebabkan oleh beberapa faktor seperti putting payudara ibu yang lecet, produksi ASI yang sedikit, strees dan ketidak pekaan ibu terhadap waktu yang tepat saat pemberian ASI dan pada responden yang memili teknik menyusui tidak tepat namun berhasil dalam menyusi dikarenakan adanya dukungan suami, psikologis ibu yang baik dalam penerimaan kehadiran anggota baru serta nutrisi yang cukup. 


\section{KESIMPULAN}

1. Umur responden berada pada rentang dewasa awal (26-35 tahun), pendidikan responden pada kategori SMA, jumlah persalinan pada kategori multipara dan cara lahir pada kategori SC

2. Teknik Menyusui sebagian besar berada pada kategori tidak tepat

3. Keberhasilan Menyusui sebagian besar berada pada kategori tidak berhasil

4. Terdapat hubungan antara Teknik Menyusui dengan Keberhasilan Menyusui Pada Bayi Di Ruangan Rawat Inap Aulia Hospital Pekanbaru Tahun 2019 (p value 0,000 $\leq 0,05$ )

\section{DAFTAR PUSTAKA}

Alam (2013). Faktor-Faktor Yang Berhubungan Dengan Teknik Menyusui Pada Ibu Di Puskesmas Pattallassang Kabupaten Takalar. Diakses pada tanggal 13 Maret 2019

Alia (2017). Frekuensi BAK pada Bayi. Diakses pada tanggal 15 Mei. http://Alodokter.com

Astuti R, (2015) Asuhan Kebidanan Masa Nifas dan Menyusui,Jakarta

Arifin S,(2014) Pendidikan Agama Islam,Yogyakarta,deepublish

Angkoso, DV, (2009) Hubungan Pengetahuan Ibu Tentang Cara Menyusui Dengan Prilaku Menyusui Bayi Usia 0-6 Bulan.https:// digilibs.UNS ac.id

Bahiyatun,(2009) Buku Ajaran Asuhan Kebidanan Nifas Normal,Jakarta,EGC

Budiman, Rianto A (2014) Kapita Selekta Kuisioner, Pengetahuan Dan Sikap Dalam Penenelitian kesehatan,Jakarta,Slemba Medika.

DepKes R1 (2016). Klasifikasi Umur Menurut WHO. Diakses pada tanggal 10 Maret 2019. www.depkes.go.id

Dinas Kesehatan Riau (2013). Profil Kesehatan Riau. Pekan Baru diperoleh tanggal 11 november 2018

Hidayat, A.A. (2011). Riset keperawatan dan teknik penulisan ilmiah. Jakarta, Salemba Medika.

Kementrian Kesehatan RI (2013). Info Datain .diperoleh tanggal 11 november 2018.

Notoatmojo, S. (2010). Metodologi Penelitian Kesehatan. Jakarta, Rineka cipta.

Novita R, (2011) Keperawatan Maternitas, Bogor,Ghalia Indonesia

Nurbaeti,I,\& Lestari, K.B (2013). Efektifitas comprehensive breastfeeding education terhadap keberhasilan pemberian air susu ibu poast partum.PSIK UIN Syarif Hidayatullah,1 (2),88-98 diunduh dari 16 desember (2018)
Nagtalon, J, \& Ramos (2014). Kesehatan Ibu Dan Bayi Baru Lahir: Pedoman Untuk Perawat Dan Bidan.Jakarta Erlangga.

Nursalam (2013) Konsep dan Penerapan Metodologi Penelitian Ilmu Keperawatan. Jakarta : Selemba Medika

Proverawati, A, \& Rahmawati,E, (2010). Kapita Selekta ASI \& Menyusui.Yogyakarta : Nuha Medika.

Rahayu, A,P (2016) Panduan Praktikum Keperawatan Maternitas, Yogyakarta, deepublish Ed 1

Rinata ,E, \& Iflahah, D, (2016)- Jurnal Kedokteran Midwifeeria,diunduh dari http://ojs Umsida .ac.id/tanggal 20 desember 2018.

Rhipiduri, R. 2014.Faktor-faktor yang Berhubungan dengan Teknik Menyusui pada Ibu Primipara. Jurnal Kebidanan dan Keperawatan, Vol. 10, No. 1, Juni 2014: 816

Romiyati, R, \& Utami,F .(2015) Hubungan Pengetahuan Ibu Tentang Teknik Menyusui dengan Prilaku Pemberian ASI Pada Ibu Menyusui, diunduh dari http://scholar

digilib.Unisayogyakarta/tanggal desember 2018.

Riyanto, A, (2014). Kapita Selekta Kuisioner :Pengetahuan Dan Sikap Dalam Penelitian Kesehatan.Jakarta,Salemba Medika.

Septikasari, M, S. ST.MPA (2018). Status Gizi Anak Dan Faktor Yang Mempengaruhi eds, 1.Yogyakarta:UNY press.

Wawan, A. (2014)._Pengetahuan, Sikap Dan Prilaku Manusia. Yogyakarta, Nuha Medika.

WHO (2014).Nutrition, exdusive breast feeding. Diunduh dari http://www.who.int tanggal 15 desember 1018 . 